\title{
MORPHOMETRIC CHANGES OF CARDIAC MAST CELLS IN RATS ACUTELY POISONED BY T-2 TOXIN
}

\author{
JAĆEVIĆ VESNA*, BOKONJIĆ $D^{*}$, STOJILJKOVIĆ M**, RESANOVIĆ RADMILA***, \\ BOČAROV-STANČIĆ ALEKSANDRA ${ }^{* * \star *}$, KILIBARDA VESNA* and POPOVIĆ $\mathrm{N}^{\star * \star * *}$ \\ *National Poison Control Centre, Military Medical Academy, Belgrade; \\ **Actavis Trading Ltd., Representative Office, Belgrade; \\ ***Faculty of Veterinary Medicine, Belgrade; \\ ****Bio-Ecological Centre, Zrenjanin \\ $\star \star \star \star * \star$ Olympus, Belgrade \\ (Received 4. July, 2006)
}

Wistar rats were treated with $T-2$ toxin $\left(1 L D_{50} ; 0.23 \mathrm{mg} / \mathrm{kg} \mathrm{sc}\right)$ and the surviving animals were sacrificed on days 1, 3, 5, 7, 14, 21 and 28 after treatment. At each time, control animals were sacrificed, too. Cardiac mast cells, previously stained by Giemsa method, were analyzed in whole visual fields, magnification $x 40$. In the present study the following quantitative morphometric parameters of cardiac mast cells were evaluated: perimeter $(P)$, area $(A)$ and roundness $(R)$. In the control groups of rats the majority of mast cells were small $(P=6.86$ $7.99 \mu \mathrm{m})$, hypogranular $\left(A=11.60-14.30 \mu \mathrm{m}^{2}\right)$ and ovoid $(R=0.60$ $0.65 \mu \mathrm{m})$. Mast cells, with discrete granules, hypergranular, had significantly different quantitative parameters $(P=12.80$ - $14.90 \mu \mathrm{m}$; $A$ $\left.=16.70-20.00 \mu m^{2} ; R=0.35-0.38 \mu \mathrm{m}\right)$. The minority of mast cells, classified as degranulated, had a large $(P=20.70-23.30 \mu \mathrm{m})$, irregular shape $\left(A=24.40-30.90 \mu m^{2}\right)$ and showed degranulation $(R=0.15$ $0.21 \mu \mathrm{m})$. In the heart of T-2 toxin-treated rats the quantitative parametar values of hypogranular mast cells and hypergranular mast cells were similar to the control group during the whole study. However, degranulated mast cells showed a significant increase in perimeter and area values $(p<0.05)$, while their roundness was decreased $(p<0.05)$ in comparison to the control groups of animals. It could be concluded that the chosen quantitative morphometric parameters of cardiac degranular mast cells are useful for the evaluation of the functional status of the rats' heart during acute T-2 poisoning.

Key words: heart, mast cells, morphometry, T-2 toxin, rat

\section{INTRODUCTION}

The trichothecene mycotoxin, T-2 toxin, is one of the most effective cytotoxic metabolites of Fusarium fungi (Ciegler, 1975), which produce after inhalation or 
consumption of contaminated food and water a toxic reaction called mycotoxicosis (Ciegler, 1980).

Administration of T-2 toxin to various animals produced signs of a shock-like syndrome characterized by massive haemorrhagies, immunological failure, cardiomyopathy and death (Anonymous, 2003). The exact causal mechanism of T-2 toxin-induced cardiomyopathy remains unclear. Many investigators consider its cardiotoxic effects just as a result of particular myocardial structural alterations, capillary damages, haemorrhagies and focal accumulations of inflammatory cells (Yarom et al., 1983; Pang et al., 1987; Borison et al., 1991; Jaćević et al., 2006). Its toxic effects on the plasma membrane caused increased membrane permeability, which eventually leads to irreversible cell injury (Sherman et el., 1987). T-2 toxin also has profound effects on ribosomes, sarcoplasmatic reticulum functions and mitochondrial respiration (Feurstein et el., 1985; Ueno, 1991; Pestka et al., 2004; Spijers and Spijers, 2004). However, available data favours the hypothesis that not all these effects are specific. They resemble lesions caused by a number of cardiotoxic drugs especially those used in antidepressant and anticancer therapy. The pathogenic mechanisms of these drugs are varied and often multifactorial (Dragojević-Simić et al., 2004). Some authors showed that pro-inflamatory action of the T-2 toxin probably is the most important mechanism of its acute cardiotoxicity (Newton et al., 1997a; Newton et al., 1997b; Bondy and Pestka, 2000; Jaćević, 2005). Regarding all these facts, it seems that T-2-induced blood vessels and myocyte damages due to the activation of a large number of mast cells (Jaćević et al., 2003).

Different activators, one of them probably $\mathrm{T}-2$ toxin, stimulate mast cells to synthesize arachidonic acid metabolites such as prostaglandins (PG), leukotrienes (LT), platelet-activating factor (PAF) and adenosine (Katz et al., 1992; Smith et al., 2000; Moller et al., 2003). These de novo sinthesized mediators play an important role during hypersensitivity and inflammation, and especially in nonspecific reactions of the heart tissue (Engels et al., 1995; Shiota et al., 2003). Several authors have suggested that mast cell (MCs) mediators may be involved in the aetiology of some forms of human and animal cardiomyopathy (Masini et al., 1985; Masini et al., 1988; Sperr et al., 1994). They consider that cardiac ischemia and reperfusion induce degranulation of mast cells, which is accompanied by oedema, arrhythmias, histamine and serotonin release, and release of sarcoplasmic enzymes (Dai and Ogle, 1990). However, there is accumulating evidence that indicates that cardiac mast cells are critically involved in cell toxicity, vascular endothelial cell proliferation and integrity, angiogenesis, fibrosis, polimorphonuclear cell activation and differentiation, immunoregulation and immunomodulation (Befus et al., 1988; Stevens and Austen, 1989). Synthesis and degranulation of pro-inflammatory mediators involves the migration and activation of macrophages and production of IL-1, IL-2, IL-6, IL-8 and TNF-alpha (Castells et al., 1991), which play an important role in the pathogenesis of T-2 mycotoxicosis (Bondy and Pestka, 2000).

The aim of this study was to evaluate the changes of three different types of myocardial mast cells (hypogranular, H0-MCs; hypergranular, H1-MCs; degranular, D-MCs) according to their perimetar, area and roundness in the heart 
Acta Veterinaria (Beograd), Vol. 57. No. 1, 47-57, 2007.

Jaćević Vesna et al:: Morphometric changes of

cardiac mast cells in rats acutely poisoned by $\mathrm{T}-2$ toxin

of acutely T-2 toxin-poisoned rats. The rationale for this experimental study was our previous study and finding that a single administration of T-2 toxin significantly increased the total number of rats' cardiac mast cells (CMCs), which showed degranulation (Jaćević et al., 2003; Jaćević, 2005).

\section{MATERIAL AND METHODS}

\section{Experimental animals and treatment}

The experiment was performed on adult Wistar rats, of both sexes, 6-8 weeks old, weighting 180-200 g (Animal House, Military Medical Academy, Belgrade). The animals were housed in plastic cages, under standard laboratory conditions $\left(21^{\circ} \mathrm{C}, 12 / 24 \mathrm{~h}\right.$ light/dark cycle, commercial food and tap water ad libitum) before being randomized into corresponding experimental groups. One day before the experiment, the animals were fasted. Rats were treated by T-2 toxin ( $1 \mathrm{LD}_{50} ; 0.23 \mathrm{mg} / \mathrm{kg} \mathrm{sc}$ ) and the surviving animals were sacrificed on days $1,3,5$, $7,14,21$ and 28 after treatment, respectively. At each time, control groups of animals were sacrificed, too. Each experimental group consisted of at least 8 animals.

The study protocol was based on the Guidelines for Animal Study no. 28212/2002 (Ethics Committee of the Military Medical Academy, Belgrade, Serbia).

T-2 toxin

The T-2 toxin used in this experiment was produced under laboratory conditions by Fusarium sporotrichoides fungi, cultivated on synthetic GPY (glucose $5 \%$, peptone $0.1 \%$, yeast extract $0.1 \%$, pH 5.4) medium. Extraction and crude purification of the toxin was performed by filtration, while definite purification and determination of T-2 toxin content was performed by gas chromatography with electron capture detection (GC-ECD) (Romer et al., 1991). $\mathrm{T}-2$ toxin was preliminarily tested on animals in order to obtain its $L D_{50}$ value, (Litchfield and Wilcoxon, 1949). It was thereafter used in the current experiment at a single dose of $0.23 \mathrm{mg} / \mathrm{kg}$ s.c. $\left(1 \mathrm{LD}_{50}\right)$.

\section{Histopathological procedure}

Animals were sacrificed and their hearts were excised and tissue samples were fixed in $10 \%$ neutral formalin for 5 days. Transmural tissue samples from the left and right ventricular wall were dehydrated in graded alcohol, xylol and embedded in paraffin blocks. Finally, $2-\mu \mathrm{m}$ thick paraffin sections were stained by Giemsa (GIM) method and studied by microscopy (40x; Olympus-2 microscope).

\section{Morphometric analysis}

Ten cardiac sections of each tissue sample were examined with a standard microscope connected to a computerized video system and analyzed with imageanalysis software (Camia, 2005) to estimate various quantitative mast cell features. From each specimen, 5-10 accidentally selected visual fields, magnified by $40 x$ were analyzed and a minimum of 100 mast cells per animal were measured 
automatically and the perimeter calculated. The perimetar, area and roundness of mast cells were measured by calculating the pixels. Data on these parameters were converted by the factor 0.4761 into $\mu \mathrm{m}$. According to their visible quantitative features (hypo-, hyper- and degranulated cells) all examined MCs classified on quantitative bases and perimetar, area and roudness range during the experiment (28 days) were as follows (Table 1).

Table 1. Morphometric classification of cardiac mast cells of untreated rats (MCs)

\begin{tabular}{|l|c|c|c|c|}
\hline $\begin{array}{l}\text { Visual characteristics } \\
\text { of MCs }\end{array}$ & $\begin{array}{c}\text { Types of } \\
\text { cardiac } \\
\text { MCs }\end{array}$ & $\begin{array}{c}\text { Perimetar } \\
\text { range } \\
(\mathrm{P})(\mu \mathrm{m})\end{array}$ & $\begin{array}{c}\text { Area } \\
\text { range } \\
(\mathrm{A})\left(\mu \mathrm{m}^{2}\right)\end{array}$ & $\begin{array}{c}\text { Roundness } \\
\text { range } \\
(\mathrm{R})(\mu \mathrm{m})\end{array}$ \\
\hline $\begin{array}{l}\text { MCs without visible } \\
\text { granules }\end{array}$ & $\begin{array}{c}\text { Hypogranular } \\
\text { HO-MCs }\end{array}$ & $5.0-10.0$ & $10.0-15.0$ & $>0.6$ \\
\hline $\begin{array}{l}\text { MCs with visible } \\
\text { granules }\end{array}$ & $\begin{array}{c}\text { Hypergranular } \\
\text { H1-MCs }\end{array}$ & $10.1-15.0$ & $15.1-20.0$ & $0.3-0.6$ \\
\hline $\begin{array}{l}\text { MCs which show } \\
\text { degranulation }\end{array}$ & $\begin{array}{c}\text { Degranular } \\
\text { D-MCs }\end{array}$ & $>15.0$ & $>20.0$ & $<0.3$ \\
\hline
\end{tabular}

Statistical analysis

Statistical evaluation was performed using commercial statistical software (Stat for Windows, R.4.5, Stat Soft, Inc., USA, 1993). All results are showed as mean $(X) \pm$ standard deviation (SD). Comparison of data was done by one-way ANOVA and post-hock analysis (Tuckey's test). The differences with values of $p<0.05$ were considered significant.

\section{RESULTS}

\section{General condition of experimental animals}

In the surviving rats, during the 28-day period of observation, no significant changes of general health status were seen. All the rats were in good shape. The hair, skin, visible mucoses and muscle tonicity were without any visible changes. Movements and co-ordination were preserved and comparable to the control animals.

\section{Morphometric evaluation of cardiac mast cells perimeter}

In the control group of rats, sacrificed after day 1, the perimeter of H0-MCs was $7.57 \pm 1.48 \mu \mathrm{m}$. It could be seen that the perimeters of H1-MC, and D-MCs were $14.61 \pm 2.03 \mu \mathrm{m}$, and $20.95 \pm 1.64 \mu \mathrm{m}$, respectively. These values were not significantly different from the other control groups of rats, during the whole experimental period (Figure 1). Single administration of T-2 toxin induced a significant increase of the perimetar of D-MCs $(p<0.05)$. The first significant increase was noticed on the first day after administration of T-2 toxin. This trend could be seen until day 14 of treatment. During the rest of the experiment 
Acta Veterinaria (Beograd), Vol. 57. No. 1, 47-57, 2007.

perimeters of D-MCs were not significantly different from the control ones. The highest perimeter of D-MCs was seen in the poisoned group sacrificed on the fifth day of the study $(33.60 \pm 3.83 \mu \mathrm{m})$. On the other hand, the perimeter of $\mathrm{HO}-\mathrm{MCs}$ and H1-MCs was similar to control groups of rats during the whole study.

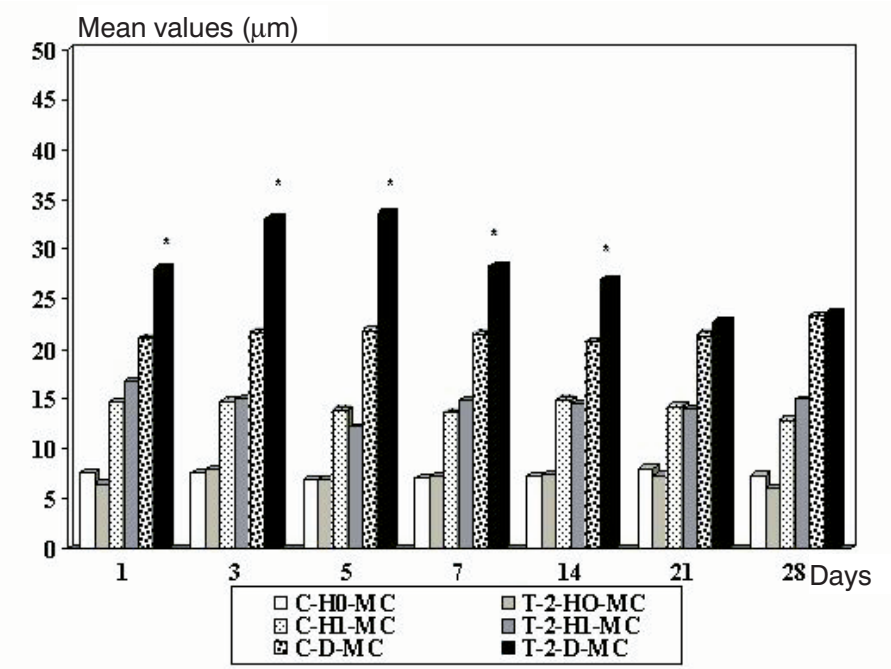

Figure 1. Time-dependent perimeter changes of cardiac MCs in control and T-2 toxintreated rats

* $=p<0.05$ vs. control group

Morphometric evaluation of cardiac mast cell area

In all control groups the areas of H0-MCs were in the range of $11.62 \pm 2.41$ to $13.1 \pm 2.41 \mu \mathrm{m}^{2}$; $\mathrm{H} 1-\mathrm{MCs}\left(16.70 \pm 5.81\right.$ to $\left.19.90 \pm 3.25 \mu \mathrm{m}^{2}\right)$; values of $\mathrm{D}-\mathrm{MCs}$ were no higher than $30.60 \pm 5.11 \mu \mathrm{m}^{2}$. The median lethal dose of T-2 toxin did not induce significant changes of the areas of HO-MCs and H1-MCs troughout the experimental study, compared to the control groups. As it is shown in Figure 2, T-2 toxin only induced a significant increase of the area of D-MCs from days 1-14 of the experiment compared to control rats. The greatest difference between T-2 toxin treated and the control group was noticed on the fifth day (39.70 \pm 5.81 versus $\left.27.00 \pm 6.01 \mu \mathrm{m}^{2} ; \mathrm{p}<0.05\right)$.

Morphometric evaluation of cardiac mast cell roundness

In the first day in the control group of animals, the roundness of HO-MCs was $0.616 \pm 0.071 \mu \mathrm{m} ; \mathrm{H} 1-\mathrm{MCs}(0.380 \pm 0.06 \mu \mathrm{m})$; and D-MCs $(0.150 \pm 0.04 \mu \mathrm{m})$. It was found that the roundness values of this type of cardiac MCs were not significantly different during the overall experimental period. The results presented in Figure 3 also cleary show that the roundness of cardiac $\mathrm{H} 1-\mathrm{MCs}$ and D-MCs in rats treated by T-2 toxin were similar to the ones in the control groups. However, T-2 itself, significantly changed only the roundness of cardiac $\mathrm{HO}-\mathrm{MCs}$ in rats sacrificed after day 7 and 14 in comparison to the control ones $(0.71 \pm 0.18$ vs. $0.62 \pm 0.07 \mu \mathrm{m} ; 0.72 \pm 0.08$ vs. $0.62 \pm 0.10 \mu \mathrm{m} ; \mathrm{p}<0.05)$. 




Figure 2. Time-dependent area changes of cardiac MCs in control and T-2 toxin-treated rats $\star=p<0.05$ vs. control group

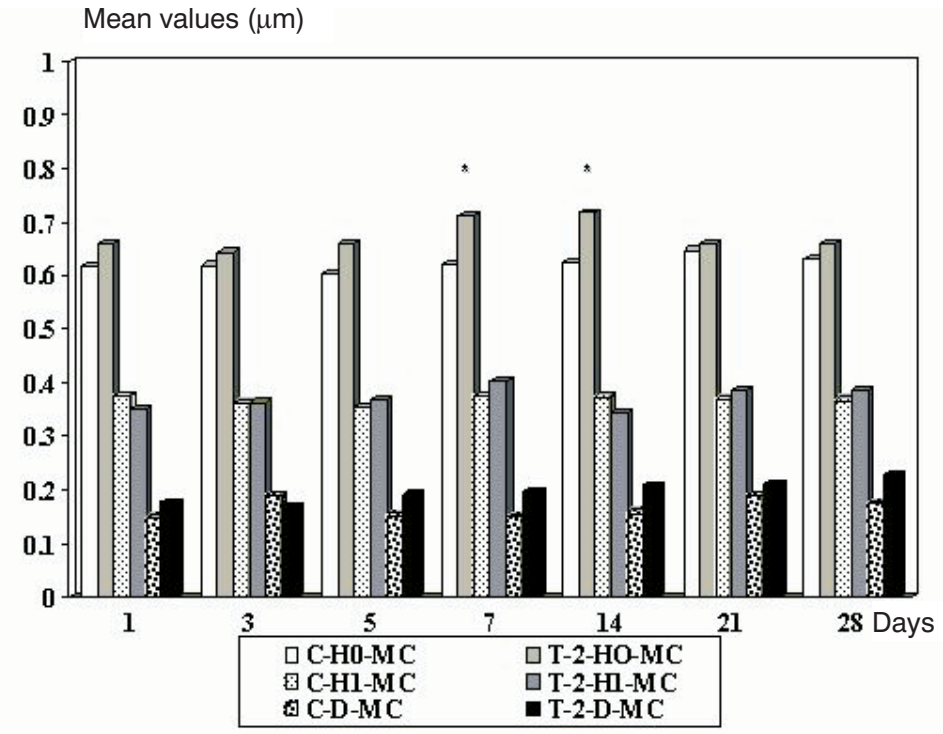

Figure 3. Time-dependent roundness changes of cardiac MCs in control and T-2 toxintreated

* $=p<0.05$ vs. control group 
Acta Veterinaria (Beograd), Vol. 57. No. 1, 47-57, 2007.

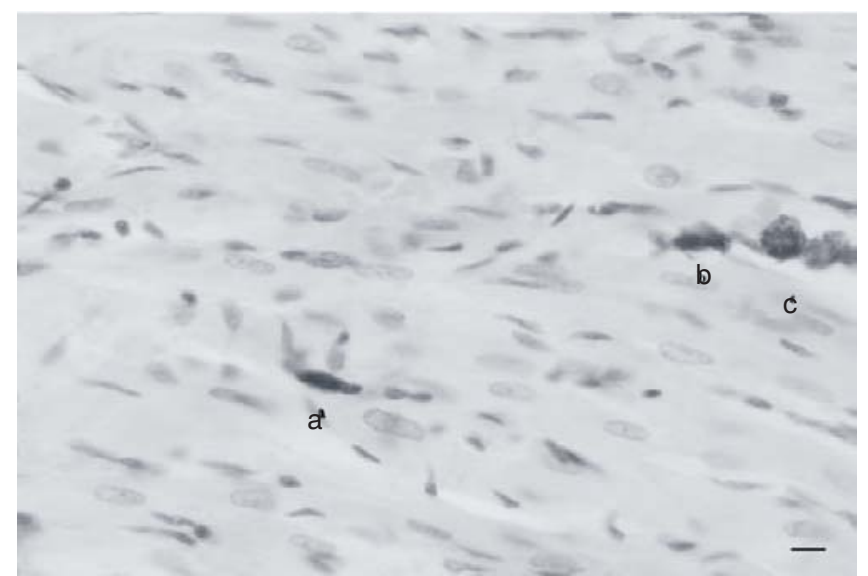

Figure 4. Perivascular localization of different types of cardiac MCs in control rat $\mathrm{a}=\mathrm{HO}-\mathrm{MCs}, \mathrm{b}=\mathrm{H} 1-\mathrm{MCs}, \mathrm{c}=\mathrm{D}-\mathrm{MCs}$, scale bar $=10 \mu \mathrm{m}$

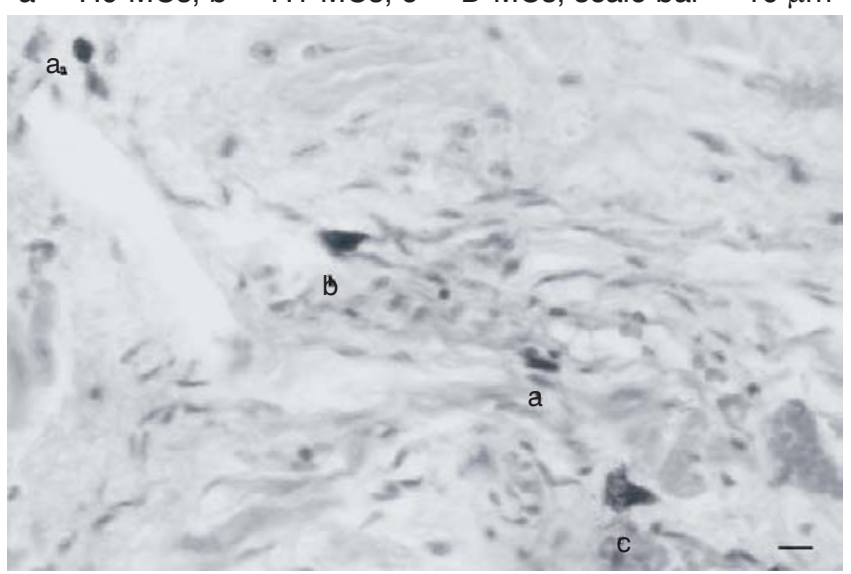

Figure 5. Diffuse tissue spreading of different types of cardiac MCs in T-2 toxin-treated rat $\mathrm{a}=\mathrm{H} 0-\mathrm{MCs}, \mathrm{b}=\mathrm{H} 1-\mathrm{MCs}, \mathrm{c}=\mathrm{D}-\mathrm{MCs}$, scale bar $=10 \mu \mathrm{m}$

\section{DISCUSSION}

In previous studies different types of cardiac MCs were monitored in the control and T-2 toxin poisoned groups of rats (Jaćević et al., 2003; Jaćević, 2005). In the present study, in the control group of rats, cardiac $\mathrm{HO}-\mathrm{MCs}$ were small $(\mathrm{P}=$ $7.57 \pm 1.48 \mu \mathrm{m})$, tiny $\left(A=11.62 \pm 2.41 \mu \mathrm{m}^{2}\right)$, ovoid $(R=0.616 \pm 0.071 \mu \mathrm{m})$ and, similarly to results reported in literature (Castells et al., 1992), they were situated on the external wall of blood vessels in the subepicardial and subendocardial regions. These findings, together with perivascular localization of $\mathrm{HO}-\mathrm{MCs}$, suggest that the basic function of the resident MCs population in the heart served for adaptive vascular changes during physiologic responses (Galli, 1993; 
Gavrisheva and Tkachenko, 2003; Boerma et al., 2005). In the control group of animals, we found that registrated parameters of $\mathrm{HO}-\mathrm{MCs}$ were highest on day 21 $\left(\mathrm{P}=7.99 \pm 1.35 \mu \mathrm{m} ; \mathrm{A}=14.33 \pm 2.18 \mu \mathrm{m}^{2} ; \mathrm{R}=0.646 \pm 0.095 \mu \mathrm{m}\right)$. The highest values of $\mathrm{H} 1-\mathrm{MC}$ were seen after the end of day $14(\mathrm{P}=14.85 \pm 3.10 \mu \mathrm{m} ; \mathrm{A}=$ $19.95 \pm 4.53 \mu \mathrm{m}^{2} ; R=0.373 \pm 0.05 \mu \mathrm{m}$ ), while these data for D-MCs were the highest on day $28\left(\mathrm{P}=23.28 \pm 0.27 \mu \mathrm{m} ; \mathrm{A}=30.85 \pm 2.28 \mu \mathrm{m}^{2} ; \mathrm{R}=0.174 \pm\right.$ $0.029 \mu \mathrm{m})$.

Our results have shown that $0.23 \mathrm{mg} / \mathrm{kg}$ single dose of T-2 toxin produced a diffuse perivascular and tissue accumulation, as well as a massive degranulation of cardiac mast cells. Later on, a single injection of T-2 toxin changed the perimetar and the area of D-MCs and their values were significantly higher than in the control groups during the study $(p<0.05)$. On the other hand, the reduction of roundness was probably associated with multiple, irregular shapes after activation and degranulation of MCs. Significantly the inrease of perimetar and area, as well a significan decrease of roundness of D-MCs in T-2 toxin-induced rats, are considered multifactorial. These are the results of direct lymphocytederived and other cytokines effects on mast cell proliferation or maturation/differentiation which are quite different than the normal levels of these products expressed at the same anatomical location under normal circumstances (Matsumori, 2005). The low doses of T-2 toxin have stumulatory effects on immune and inflammation associated genes, Th1 and Th2 cytokines as well as chemokines, COX-2 and inducible nitric oxide synthase. Some authors confirm that T-2 toxin has a great ability to induce interleukin-2 (IL-2) production (Feurstein, 1985). IL-2 is a potent T lymphocyte growth factor, which causes proliferation of natural killer (NK) cells and cytotoxic T lymphocytes. It also interacts with macrophages and enhances the activity of cytotoxic T cells (Robb, 1984). The targeting of such cells onto the heart may be due to their previous sensitization by damaged cardiac tissue in the T-2 toxin-treated rats. The sites of cardiac alterations, with a large numbers of eosinophils, may have a high concentration of molecules (e.g. IgE and specific antigens) which alter mast cell phenotype as a consequence of inducing its degranulation (Fox and Lakshamanan, 1994; Newton et al., 1997a; Newton et al., 1997b). Similar to these facts, our morphometric evaluation has shown that excessive degranulation of cardiac mast cells was during the first 2 weeks of the experiment. The most prominent perametar of D-MCs was on day $5\left(P=33.6 \pm 3.83 \mu \mathrm{m} ; A=39.66 \pm 5.68 \mu \mathrm{m}^{2}\right.$; $\mathrm{p}<0.05)$. The pathophysiological function of the cardiac mast cell population in $\mathrm{T}$ 2 toxin-treated rats is still unclear. On the other hand, the activated mast cells, in the present study named as $\mathrm{H} 1-\mathrm{MCs}$, around the newly formed blood vessels may cause the fragile microvessels to fracture with resulting local hemorrages (Kaartinen et al., 1996; Akgul et al., 2005). These observations point to a possible role of cardiac mast cells in the local microenvironmental and vasculaar events in the haert, especially during the development of ishaemia caused by T-2 toxin.

Morphological changes of D-MCs in our experiments were verified by functional alterations in these cells during degranulation. It should be mentioned that the mechanism of mast cell degranulation includes the extrusion of granules to the exterior wall of the cell, as well as intracytoplasmic solubilization of granules 
and fusion of its membranes, and formation of degranulation channels (Dvorak, 1991). This activation may be induced by macrophages (Ueno, 1991) and T lymphocytes (Lui et al., 1986; Sedgewick et al., 1981), two pro-inflammatory cell types that are present in perivascular infiltrations in the region of T-2 toxin-induced vascular and cardiac damages are confirmed in our recent studies (Jaćević et al., 2001; Jaćević et al., 2005).

It could be concluded that the chosen quantitative morphometric parameters of D-MCs are useful only for the evaluation of the functional status of the heart during acute T-2 toxicosis. Therefore, further investigations are necessary to establish the correlation between the MCs degranulation and miocardial alterations in rats acutely poisoned by T-2 toxin.

Address for correspodence:

Vesna Jacevic, DVM, PhD, pathologist, assistant professor

Department of experimental toxicology and pharmacology

Institute of toxicology and pharmacology

National Poison Control Centre

Military Medical Academy

Crnotravska 17, 11000 Belgrade, Serbia

E-mail: petmedic@net.yu

\section{REFERERNCES}

1. Akgul A, Youker K, Noon G, Loebe M, 2005, Quantitative changes in mast cell population after ventricular assist device implantation, ASAIO J, 52, 3, 275-80.

2. Anonymous, 2003, Medical classification of potential BW agents 3 Toxins. J R Army Med Corps, 149, 219-23.

3. Befus D, Fujimaki H, Swieter M, 1998, Mast cell polymorphisms: Present concepts, future direction, Diges Dis Sci, 33, S16-24.

4. Boerma M, Wang J, Wondergem J, Joseph J, Qiu X et al, 2005, Influence of mast cells on structural and functional manifestations of radiation-induced heart disease, Cancer Res, 65, 8, 3100-7.

5. Bondy G, Pestka J, 2000, Immunomodulation by fungaltoxins, J Toxicol Env Health B Crit Rev, 3 , 109-43.

6. Borison L, Goodhearth L, Thut C, 1991, Hypovolemic shock in acute lethal T-2 mycotoxicosis, Toxicol Appl Pharmacol, 108, 107-13.

7. Castells M, Katz H, Austen K, 1992, Molecular and cellular biology of rodent mast cells, Int Arch Allergy Immunol, 99, 189-95.

8. Ciegler A, 1975, Mycotoxins: Occurrence, chemistry, biological activity, Lloydia, 38, 1, 21-35.

9. Ciegler A, Bennett W, 1980, Mycotoxins and mycotoxicosis, Biosci, 30, 8, 512-5.

10. Dai S, Ogle C, 1990, Ventricular histamine concentrations and mast cell count in the rat heart during acute ischaemia, Agent Actions, 29, 138-43.

11. Dragojević-Simić V, Dobrić S, Bokonjić D, Vučinić Z, Sinovec $S$ et al, 2004, Amifostine protection against doxorubicin cardiotoxicity in rats, Anti Canc Drug, 15, 2, 169-78.

12. Dvorak A, 1991, Basophile and mast cell degranulation and recovery. Blood Cell Biochemistry, New York: Plenum Press, 4, 199-202.

13. Engels W, Reiters P, Daemien M, Smits J, Van Der Vusse G, 1995, Transmural changes in mast cell density in rat hearth after infarct induction in vivo, $J$ Pathol, 177, 423-9.

14. Feurstein G, Goldstein D, Ramwell P, Zerbe R, Lux W et al, 1985, Cardio respiratory, sympathetic ans biochemical response to T-2 toxin in the quinea pig and rat, J Pharmacol Exp Ther, 232, 786-94.

15. Fox C, Lakshamanan R, 1994, Rat mast cells express accessory molecules for antigen presentation, FASEB J, A498. 
16. Galli S, 1990, Biology of disease. New insights into "the riddle of the mast cells": Microenvironvironmental regulation of mast cell development and phenotypic heterogeneity, Lab Inv, 62, 1, 5-33.

17. Galli S, 1993, New concept about mast cell, N Engl J Med, 328, 257-65.

18. Gavrisheva N, Tkachenko S, 2003, Mast cells in normal and disease heart, Kardiol, 43, 6, 59-65.

19. Jaćević V, Zolotarevski L, Jelić K, Stanković D, Milosavljević I et al, 2001, Effects of new antidotal combinations on pathohistological changes in hearts of rats acutely poisoned with T-2 toxin, Iugoslav Phisiol Pharmacol Acta, 37, 2, 49-58.

20. Jaćević V, Zolotarevski L, Jelić K, Dimitrijević J, Kilibarda V et al, 2003, Detection of cardiac mast cells in rats poisoned by T-2 toxin, Virch Arch, 443, 3, 474.

21. Jaćević $V, 2005$, Therapy of acute T-2 toxin poisoning in rats. (in Serbian), Belgrade: Andrejevic Fondation, 1-127.

22. Jaćević V, Zolotarevski L, Milosavljević I, Jelić K, Resanović $R$ et al, 2005, Influence of different glucocorticosteroid treatment regimens ion pathohistological changes in heart of rats poisoned with T-2 toxin, Acta Vet, 56, 2-3, 243-57.

23. Kaartinen M, Penttila A, Kovanen P, 1996, Mast cells accompany micro vessels in human coronary athermos: implications for intimal neovascularization and hemorrhage, Atheroscl, 12, 123-31.

24. Katz H, Raizman M, Gartner C, Scott H, Benson A et al, 1992, Secretory granule mediator release and generation of oxidative metabolites of arachidonic acid via Fc ( $R$ bridging in mouse mast cells, J Immunol, 148, 2155-62.

25. Litchfield J, Wilcoxon F, 1949, A simplified method of evaluating dose-effects experiments, $J$ Pharmacol Exp Ther, 96, 99-113.

26. Lui M, Proud D, Lichtenstein L, MacGlashan D, Schleimer R et al, 1986, Human lung macrophagesderived histamine-releasing activity is due to IgE-depend factors, $J$ Immunol, 136, 2588-95.

27. Masini E, Phachhenault J, Pezziardi F, Gautier P, Gagnol J, 1985, Histamine releaser during experimental coronary thrombosis in awake dog, Agents actions, 16, 227-30.

28. Masini E, Giannella E, Bianchi S, Palmerani B, Pistelli $A$ et al, 1988, Histamine release in acute coronary occlusion-reperfusion in isolated guinea-pig heart, Agents Actions, 23, 266-9.

29. Matsumori $A, 2005$, Cytokine antagonist and endothelia antagonist for therapy of heart failure, Nippon Naika Gakkai Zasshi, 51, 3, 275-80.

30. Moller C, Xiang Z, Nilsson G, 2003, Activation of mast cells by immunoglobulin E-receptor crosslinkage, but not through adenosine receptors, induces $A 1$ expression and promotes survival, Clin Exp Allergy, 33, 8, 1135-40.

31. Newton R, Kuitert L, Bergmann M, Adcock I, Barnes P, 1997a, Evidence for involvement of NF-êB in the transcriptional control of COX-2 gene expression by IL-1â, Biochem Biophys Res Commun, 237, 28-32.

32. Newton R, Stevens D, Hart L, Lindsay M, Adcock I et al, 1997b, Superinduction of COX-2 mRNA by cycloheximide and IL-1â involves increased transcription and correlates with increased NF-êB and JNK activation, FEBS Lett, 418, 135-8.

33. Pang V, Lorenzana R, Baesley V, Buck W, Haschek W, 1987, Experimental T-2 toxicosis in swine. III. Morphologic changes following intravascular administration of T-2 toxin, Fundam Appl Toxicol, 8, 298-309.

34. Pestka J, Zhou H, Moon Y, Chung Y, 2004, Cellular and molecular mechanisms for immune modulation by deoxynivalenol and other trichothecenes: unraveling a paradox, Toxicol Lett, 153, 61-73.

35. Robb R, 1984, Interleukin-2: the molecule and its function, Immunol Today, 5, 203-9.

36. Romer T, Boling T, McDonald J, 1987, Gas-liquid chromatographic determination of the T-2 toxin and diacetoxyscirpenol in corn and mixed feeds, J Assoc Anal Chem, 61, 801-8.

37. Sedgewick J, Holt P, Turner K, 1981, Production of a histamine-relishing lymphokine by antigen- or mitogen-stimulated human peripheral T cells, Clin Exp Immunol, 45, 409-418.

38. Sherman Y, More R, Yagen B, Yarom R, 1987, Cardiovascular pathology induced by passive transfer of splenic cells from syngeneric rats treated with T-2 toxin, Toxicol Lett, 36, 15-22. 
Acta Veterinaria (Beograd), Vol. 57. No. 1, 47-57, 2007.

Jaćević Vesna et al:: Morphometric changes of

cardiac mast cells in rats acutely poisoned by T-2 toxin

39. Shiota N, Rysa J, Kovanen P, Ruokoaho H, Kokkonen J et al, 2003, A role of cardiac mast cells in the pathogenesis of hypertensive heart disease, J Hypertens, 21, 10, 1935-44.

40. Smith W, DeWitt D, Garavito R, 2000, Cyclooxygenases: structural, cellular, and molecular biology, Annu Rev Biochem, 69, 145-82.

41. Speijers G, Speijers M, 2004, Combined toxic effects of mycotoxins, Toxicol Lett, 153, 91-8.

42. Sperr W, Bankl H, Mundigler G, Klappacher G, Grobschmidt K et al, 1994, The human cardial mast cell: Localization, isolation, phenotype, and functional characterization, Blood, 84, 3876-84.

43. Stevens R, Austen K, 1989, Recent advances in the cellular and molecular biology of mast cells, Immunol Tod, 10, 381-5.

44. Ueno Y, 1991, Biochemical mode of action of mycotoxin, Mycotoxins and Animal Foods, Boca Raton: CRC Press, 437-45

45. Yarom R, More R, Sherman Y, Yagen B, 1983, T-2 toxin-inducted pathology in the hearts of rats, $\mathrm{Br} J$ Exp Path, 64, 557-70.

\title{
PROMENE MORFOMETRIJSKIH PARAMETARA MASTOCITA U SRCU PACOVA AKUTNO TROVANIH T-2 TOKSINOM
}

\author{
JAĆEVIĆ VESNA, BOKONJIĆ D, RESANOVIĆ RADMILA, BOČAROV-STANČIĆ \\ ALEKSANDRA, KILIBARDA VESNA, STOJILJKOVIĆ M i POPOVIĆ N
}

\section{SADRŽAJ}

Preživeli Wistar pacovi, tretirani T-2 toksinom (1 LD $\mathrm{LD}_{50} ; 0,23 \mathrm{mg} / \mathrm{kg} \mathrm{sc}$ ), žrtvovani su 1, 3, 5, 7, 14, 21. i 28. dana posle tretmana. $U$ istim vremenskim intervalima žrtvovane su životinje iz kontrolnih grupa. Mastociti srca, prethodno obojeni primenom Giemsa metode bojenja, analizirani su u celom vidnom polju, pod uveličanjem 40. U ovom radu ispitivani su sledeći kvantitativni morfometrijski parametri: perimetar $(P)$, površina $(A)$ i kružnost $(R)$. U srcu kontrolne grupe pacova mastocititi su većinom sitni $(P=6,86$ - 7,99 $\mu \mathrm{m})$, hipogranularni $(A=11,60$ $\left.14,30 \mu \mathrm{m}^{2}\right)$ i ovalnog oblika $(R=0,60-0,65 \mu \mathrm{m})$. Mastociti blago ispunjeni granulama, hipergranularni mastociti, imali su statistički značajno različite vrednosti kvantitativnih parametera $\left(P=12,80\right.$ - 14,90 $\mu \mathrm{m} ; A=16,70-20,00 \mu \mathrm{m}^{2} ; R=0,35$ $0,38 \mu \mathrm{m})$. Mali broj mastocita označeni kao deganulirani mastociti su veliki $(P=$ $20,70-23,30 \mu \mathrm{m})$, nepravilnih oblika $\left(A=24,40-30,90 \mu \mathrm{m}^{2}\right)$ sa granulama ispražnjenim u okolno tkivo $(R=0,15-0,21 \mu \mathrm{m})$. U srcu pacova tretiranih T-2 toksinom kvantitativni parametari hipogranuliranih i hipergarnuliranih mastocita imali su vrednosti slične kontrolnim grupama životinja tokom celog perioda ispitivanja. Međutim, degranulirani mastociti pokazali su statistički značajno povećanje vrednosti prečnika i površine $(p<0,05)$, dok je njihova kružnost bila manja $(p<0,05) u$ poređenju sa kontrolnim grupama pacova. Moglo bi se zaključiti da su ispitivani kvantitativni morfometrijski parametri degranuliranih mastocita korisni za ispitivanje funkcionalnog statusa srca pacova akutno trovanih T-2 toksinom. 